\title{
Studies on Enzymatic Proteolysis of Reduced Glutathione (GSH)- Treated Thyroid Protein Iodinated to Different Degrees
}

\author{
Hidekazu ISHII, Isao KOBAYASHI and Setsuo KOBAYASHI \\ First Department of Internal Medicine, School of Medicine, Gunma University, Maebashi, Japan
}

Many investigators have found that the degree of iodination of thyroglobulin (Tgb) is directly correlated with its resistance to a variety of agents, such as alkali, heat, sodium dodecyl sulfate and freezing. It is also known that GSH enhanced the release of iodoamino acids from Tgb during endogenous proteolysis.

No detailed information is available on the effect of GSH on proteolytic digestion of Tgb with different degrees of iodination. The present study was undertaken to determine the effect of GSH disruption of disulfide bonds of Tgb molecules on the susceptibility to in vitro enzymatic attack. The thyroids of rats fed on a high iodine or low iodine diet were labeled with ${ }^{131} \mathrm{I}$ in vivo. With the preincubation of GSH, the following results were obtained.

1) Poorly-iodinated thyroid was more sensitive to autolysis than was highly-iodinated thyroid.

2) Increased sensitivity to autolysis in poorly-iodinated thyroid was considered not to be due to stimulation of thyroid protease activity mediated by TSH.

3) Poorly-iodinated protein was more readily degraded than highly-iodinated protein by thyroid protease, pepsin and pancreatin under the various $\mathrm{pH}$ ranges.

Since GSH is known to disrupt disulfide bonds and permit dissociation of Tgb molecules more readily, these observations support the concept that the exposure of the disulfide bonds to attack is greater in poorly-iodinated than in highly-iodinated Tgb. It is also suggested that reduction of disulfide bonds may be of considerable importance in the normal intrathyroidal proteolysis of Tgb.

(See pp. 1319 1327) 


\title{
甲状腺蛋白加水分解に及ぼす還元グルタチオンの効果
}

\author{
群馬大学医学部第一内科学教室 \\ 小 林 節 雄
}

石 并秀 和, 小 林功

(昭和 48 年 2 月 19 日受付)

Thyroglobulin のヨード化の程度が in vitro の蛋白加水分解過程に, ぞのように影響を及ぼすが 検討した. ${ }^{131}$ I-標識ラット甲状腺 autolysis は還元グルタチオンで明らかに促進し，その割合は，ヨー ド化の少い甲状腺がヨード化の進んだ甲状腺より著明であつた．との還元グルタチオンの autolysis 促 進効果は thyroid protease 活性への刺激よりも, 標識甲状腺蛋白の S-S 基の還元によるものと考えら れる.

\section{はじめに}

甲状腺ホルモンは, 甲状腺内の thyroglobulin (TGB) 分子の中で合成され, 通常, 甲状腺沪胞の中に コロイドとして貯蔵されている. 甲状腺刺激物質, 例えば, TSH を生体に注射すると, 甲状腺沪胞内にあ るコロイドは細胞内にある加水分解醳素と結合 (fuse) してから、ヨード化アミノ酸を遊離するてと（proteolysis) は広く知られている122).

最近，Peake 等 ${ }^{3}$ は沪胞内に貯えられた甲状腺蛋白が加水分解作用を受ける前には，まず蛋白の $S-S$ 基が 還元され, 加水分解酵素の作用を受け易い形に変えられるという仮説を発表した。更に，彼等は蛋白の $\mathrm{S}-\mathrm{S}$ 結合の還元に関与する物質，甲状腺内の還元に関与する物質は，甲状腺内の還元グルタチオン (GSH) で あろうと推論した ${ }^{4}$. 一方, TGB はそのヨード化 (iodination) の程度により, 著しくその性状を変化し 得ることが知られている゙

TGB の物理化学的研究から得た，ての特性は一体どのような生理的意義をもつものであろうか. 甲状腺 ホルモン分泌機構に関する限り, 殆んど, ての点に関して従来の研究では問題にされなかつた，そてで, わ れわれは今回の実験において，生体の生理的状態を考慮に入れながら，蛋白のヨード化の違いが甲状腺蛋白 加水分解の割合を規定する可能性を探るために，以下のような一連の実験を行つた。

\section{I 実嗝方法および材料}

\section{1 ）標準甲状腺蛋白源}

Wistar 系の 150〜200g の雄ラットを全実験を通して使用した。 まず，動物を二群に分け，高ヨード食 (Purina chow laboratory diet, Purina, $1 \mathrm{mg} \mathrm{I} / \mathrm{kg}$ ) 又は, 低ヨード食 (Remington type Low iodine diet. LID, $75 \mu \mathrm{g} \mathrm{I}-/ \mathrm{kg})^{12) 13)}$ でそれぞれ一定期間飼育した。特に甲状腺内のヨード化を防ぐ目的で, LID 飼 育動物に一日 $15 \mathrm{mg} の$ propylthiouracil (PTU) を一日 2 回に分けて皮下注射し, 一週間後PTU を中止し て，LID 食単独に切り換えた。乙のような操作は既に報告したように ${ }^{14)}$ ，甲状腺内のヨード量は測定不可 能な程度に少量となる $\left(0.1 \mu \mathrm{g}{ }^{127} \mathrm{I} /\right.$ 用状腺以下). 次いで, 各群の動物に $20 \sim 50 \mu \mathrm{C} の$ carrier-free ${ }^{131} \mathrm{I}$ t 腹腔内に注射し，通常動物の甲状腺を in vivo で 4 時間標識して，剔出した。闸状腺は， $0.5 \mathrm{ml} の 0.9 \%$ 食塩水中で homogenize し, ての homogenize した溶液は, 更に $1 \mathrm{ml}$ あたり甲状腺蛋白 $2 \mathrm{mg}$ を含むよう に, $0.9 \%$ 食塩水で調整し, 標準甲状腺 homogenate を作成した。既に報告したように占，われわれは 
この標識甲状腺 homogenate を便宜上，thyroglobulin（TGB）と見做すとととした。

2 ）加水分解酵素源

加水分解酵素源として様々な濃度の pancreatin (関東化学) を $\mathrm{pH} 8.5$ の Tris buffer で, pepsin（ミク 二化学産業, 1:5,000) を pH 2.0 のGl-HGl buffer 中で使用した. 又, crude の thyroid protease を Pitt-Riveres 等 ${ }^{16)}$ の方法に若干の修正を加え，pH 3.6 で使用した ${ }^{17)}$. 甲状腺 autolysis を行う実験では， Beckers 等18) の方法によつた. 即ち, 予め in vivo で標識した甲状腺を用い, $0.15 \mathrm{M}$ の食塩水 $2 \mathrm{ml}$ 中に 甲状腺スライス $100 \mathrm{mg}$ 夻含むようにし， $4{ }^{\circ} \mathrm{C} て ゙ 24$ 時間 incubate し，毎分 3,000回転の速度で10分間遠沈し， その上清を “thyroid extract”とした。とれは甲状腺コロイド物質を含み，特に TGB と lysosome 及び Phagolysosome の混合したものといわれている ${ }^{18)}$.

\section{3 ）標識ヨード化蛋白の変性}

標識ヨード化蛋白の変性のためには， $0.1 \mathrm{ml}$ の様々の濃度 $\left(1 \times 10^{-1} \sim 1 \times 10^{-5} \mathrm{M}\right)$ の還元グルタチオン $(\mathrm{GSH})$ を $0.1 \mathrm{ml}$ の標識蛋白の溶液又は $0.1 \mathrm{ml}$ の thyroid extract へ加光て（従つて，GSH の濃度は $5 \times$ $10^{-2} \sim 5 \times 10^{-6} \mathrm{M}$ となる. )，30分間，室温に放置した。

\section{4 ) Incubation mixture の作成}

Incubation mixture の全量は $0.5 \mathrm{ml}$ で, 上記標識蛋白源 $0.1 \mathrm{ml}$ に, GSH を含むbuffer 又は対照群では buffer のみ $0.1 \mathrm{ml}$ を添加した後, $1 \mathrm{mg} の$ methylmercaptoimidazole (MMI) 及び様々な濃度の加水分解

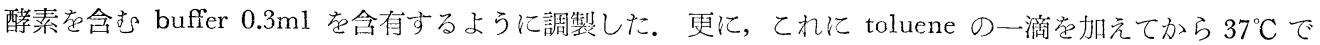
24時間 incubation を行った. 又, autolysis の実験では $0.1 \mathrm{ml}$ の thyroid extract に様々な濃度の GSH を含む buffer 又は, 詨照群では bufferのみ $0.1 \mathrm{ml}$ 添加した後, $1 \mathrm{mg} の \mathrm{MMI}$ を含む $0.2 \mathrm{ml}$ の acetate buffer ( $\mathrm{pH}$ 3.6) を加えた.

\section{5 ）加水分解の割合}

Incubation 開始 4 時間及び 24 時間後に, incubation mixture の一定量を Whattmann $3 \mathrm{MM}$ ペーパー クロマト紙にのせ, n-butanol-acetic acid-water (BAW, $4: 1: 5$ ) 及び n-butanol-absolute ethanol-0.25N ammonia (BEA, $5: 1: 2$ ) 両系で展開した. 蛋白の加水分解の制合は，既に報告したように paperchromatogram 上に認められる origin material (O.M.) 在比較するてとによつて, 次のような式で算定され Student の t-test で統計的処理を行つた.

$$
\begin{aligned}
& \text { O.M. }(\%)=\frac{\mathrm{O} . \mathrm{Mx}}{\mathrm{O} . \mathrm{Mo}} \times 100 \\
& \text { O.M. }(\%): \text { corrected O.M. } \\
& \text { O.Mx } \quad \text { 加水分解後のO.M. } \\
& \text { O.Mo } \quad \text { : 加水分解前のO.M. }
\end{aligned}
$$

\section{II 実 験 成 績}

\section{1 ）高ヨード食及び低ヨード食飼育動物の標識甲状腺 autolysis の比較}

Purina 及び LID 動物の甲状腺を，それぞれ ${ }^{131} \mathrm{I} て ゙ 4$ 時閒標識した後に甲状腺を剔出した。直ちに甲状 腺スライスを作成し, thyroid extract とした。

Fig. 1 に示すように, GSH が存在しないとO.M.は約 $80 \% の$ 值を示し, Purina 及び LID 両群から得た 甲状腺の autolysis で全く差異を認めなかつた。一方，0.05Mの GSH で thyroid extract を autolysis 前 に処理しておくと，その後のO.M.は明らかに減少した $(\mathrm{P}<0.05, \mathrm{n}=6)$. しかし，GSHによる O.M.の 減少効果は Purina 群より LID 群の方により著明であつた. ての結果から, GSH で予めヨード化の少い 蛋白はヨード化の進んだ蛋白に比較して autolysis され易くなることが判つた.

\section{2 ）甲状腺蛋白加水分解に及ぼす GSH の濃度変化}

LID 動物の甲状腺を in vivo で 4 時間 ${ }^{131} \mathrm{I}$ で標識してから thyroid extract を作成し，この $0.1 \mathrm{ml}$ に様々 
の濃度の GSH $\left(5 \times 10^{2} \sim 5 \times 10^{-6} \mathrm{M}\right)$ を $0.1 \mathrm{ml}$ 添加 し，30分室温に放置した。その後 $\mathrm{pH} 3.6$ の acetate buffer 中で24時間 autolysis を行つた. Fig. 2 に見ら れるように, O.M.は $5 \times 10^{-2} \mathrm{M}$ で著明に減少し, 従 つて autolysis は明らかに促進した $(\mathrm{P}<0.05, \mathrm{n}=4)$. しかし，乙の濃度以下の GSH 投与群では対照群に比 較してO.M.は全く変化しなかつた。

3 ）甲状腺 autolysis に及ぼす TSH の効果（I）

In vivo に投与したTSH の効果が本実験に使われ た autolysis の系に影響を及ぼすかどうかを検討し た.まず LID 飼育動物の甲状腺を in vivoで 4 時間 標識し，それ以後の甲状腺内ヨード化アミノ酸分布の変動を防止するために $30 \mathrm{mg} の \mathrm{MMI}$ を腹腔内に注射 して，4 時間後, 様々な濃度の TSH (50〜5,000mU) を尾静脈から注射した. 又, 対象群では TSHの代 りに $0.9 \%$ 食塩水を注射した. 次いで30分後に明状腺を剔出し, 甲状腺スライスを作成した. Fig. 3 に示すよ うに，4 時間及び24時間の autolysis の割合は対照群及び TSH 投与群共に差異を認めなかつた $(\mathrm{P}>0.1, \mathrm{n}=6)$.

Fig. 2. Effect of graded doses of GSH on the autoproteolytic activity of rat thyroids

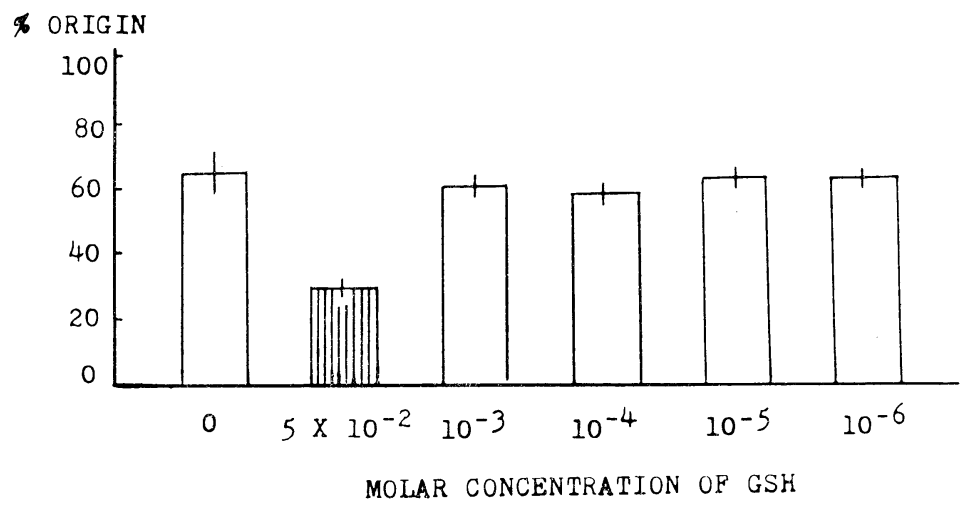

Fig. 3. Effect of graded doses of TSH on the autoproteolytic activity of rat thyroids (I)

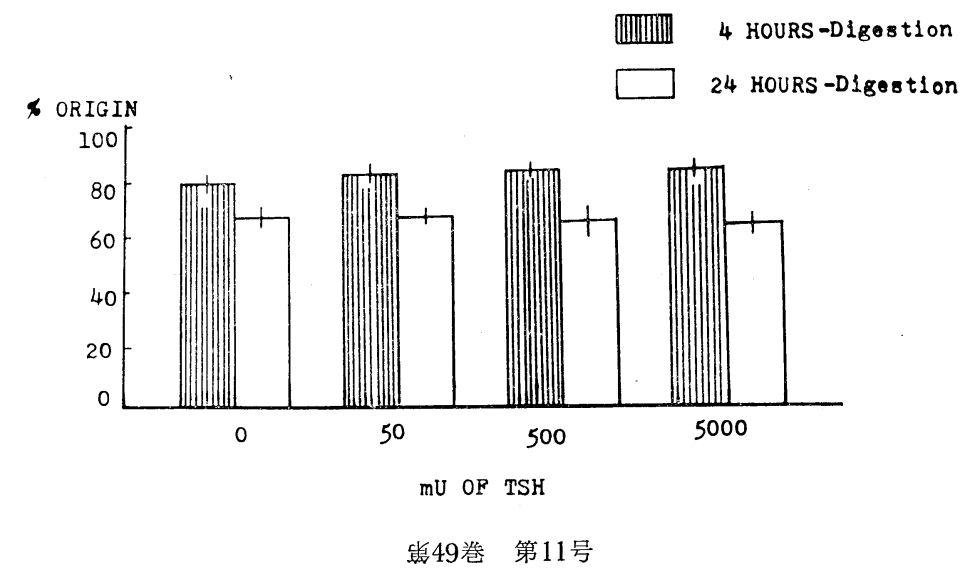


Fig. 4. Effect of graded doses of TSH on the autoproteolytic activity of rat thyroids (II)

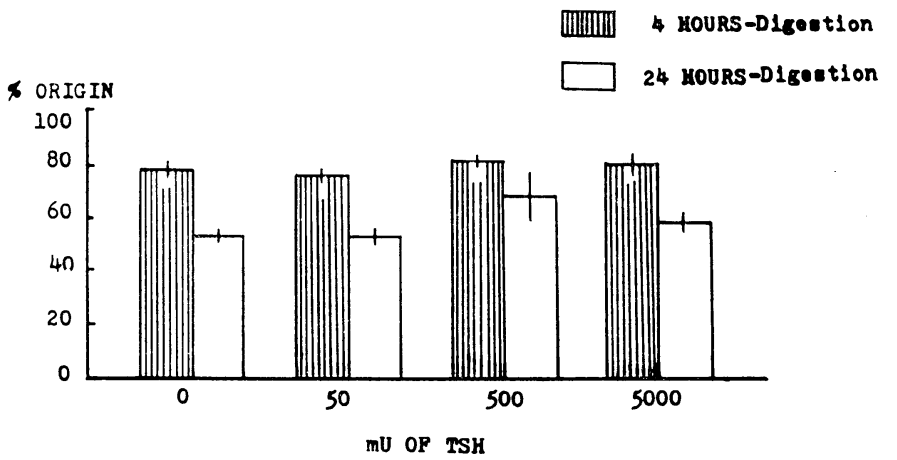

Fig. 5. Comparison of susceptibiliy to proteolysis of labeled iodoprotein from Purina and LID-fed rats

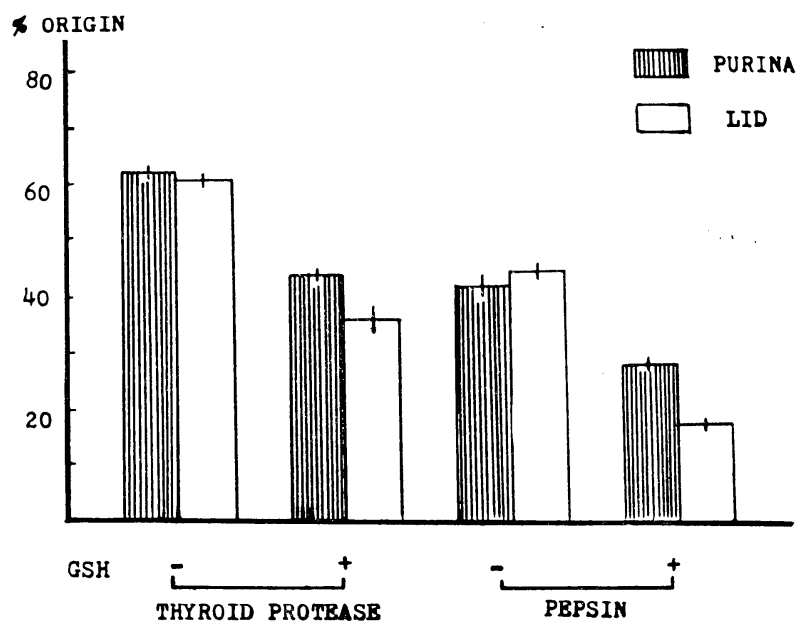

\section{4 ）甲状腺 autolysis に及ぼす TSH の効果（II）}

In vivo に投与した TSH の効果が crude の thyroid protease 活性に影響を有するかどうかを検討した. まず，LID 飼育動物に TSH (50〜 5,000 mU) を尾静脈から注射して，30 分後に甲状腺を剔出して thyroid protease を作成した，次いで別の動物から作成した標識甲状腺蛋白に，乙てで作成した $0.1 \mathrm{ml} の$ 加水分解 酵素源を添加した後，4 時間及び24時間加水分解を行つた. しかし，Fig. 4 に示すように対照群及び TSH 投与群共に差異を認めなかつた $(\mathrm{P}>0.1, \mathrm{n}=6)$.

5 ）高ヨード食及び低ヨード食飼育動物からの得た甲状腺蛋白の Pepsin 及び thyoid protease に対す る感受性の比較

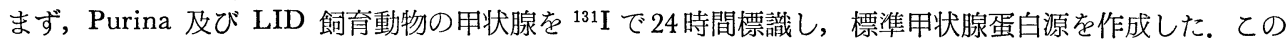
$0.1 \mathrm{ml}$ に $0.05 \mathrm{M}$ の GSH 又は対照群では $0.9 \%$ 食塩水 $0.1 \mathrm{ml}$ を加え，30分間室温に放置した．乙れに 0.0075 $\%$ pepsin 又は $20 \mathrm{mg}$ の thyroid protease を加え, $\mathrm{pH} 3.6$ の acetate buffer 中で 4 時間加水分解を行つた. Fig. 5 に示すように, GSH が存在しないと両群で加水分解の割合には差異がなかつた. しかし GSH で予 
めヨード化蛋白を処理すると LID 群の O.M. 価は Purina 群の場合より明らかに少なかつた $(\mathrm{P}<0.05$, $\mathrm{n}=6$ ).

\section{6 ）標準蛋白 proteolysis に及ぼす GSH の効果 の特異性}

予め, Purina 及び LID で飼育した動物からそれ ぞれ標準甲状腺蛋白源を作成した後，0.05M の GSH で処理した場合と処理しない場合とで, pancreatinに よるヨード化蛋白の加水分解の割合を検討した.Fig. 6 に示すように，0.005〜0.01\%の pancreatin では Purina 飼育動物から得たヨード化蛋白の加水分解の 割合は GSH を加えても，加えない場合に比較して殆 んど変化しなかつた。 それに反し，LID 飼育動物か ら得たヨード化蛋白の加水分解の割合は GSH で予 め処理すると, pancreatin の濃度の増加するのにつ れて，著明に促進した。

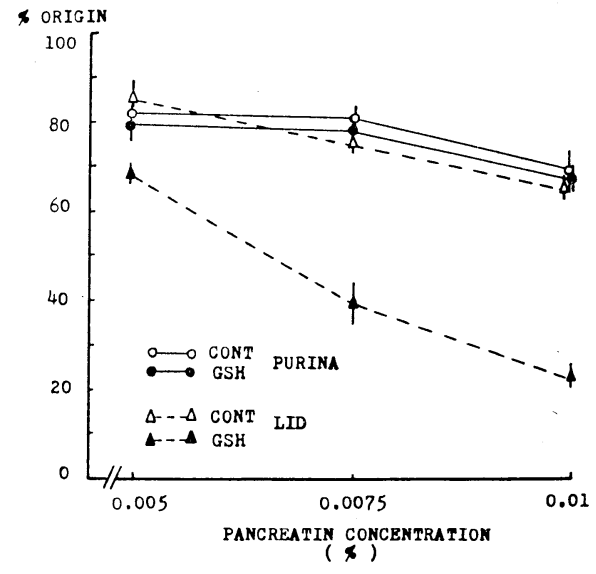

Fig. 6. Comparison of susceptibility to proteolysis of labeled iodoprotein from Purina and LID-fed rats

\section{III 考按}

TGB のヨード量乃至ヨード化の程度が TGB の stability を決定する重要な因子であるというととはよ く知られている ${ }^{5) ~ 11)}$. 特に近年, 物理化学の発展に伴い, 各種の薬物処理がこの蛋白の stability に影響を 与えるととが判つてきた。 とりわけ Edelhoch ${ }^{6)}$ やRobins ${ }^{7)}$ 等の著明な論文では，蛋白のヨード化が進むと アルカリや温度に対する stability が減少して, より小さい subunits に分れ易いとしているのに反し, 他 の論文では，むしろ蛋白分子のヨード化が進むと蛋白の freezing ${ }^{11)}$, sodium dodecyl sulfate (S.D.S.) ${ }^{8) 9) 10)}$, succinic anhydride ${ }^{10)}$ 等 に対する stability は增強するとし，最近では後者が定説になつてきている.

一方, 蛋白のヨード化が増して, その stability が増大する理由としては TGB の covalent の disulfide bonds が関係するといわれる. 19S TGB を形成する 12S subunits の covalent (disulfide) bonds は蛋白 のヨード化の進む過程で作られるらしい ${ }^{5)}$. 最近, Edelhoch 等は $5 \mathrm{M}$ の guanidine の存在下で $\mathrm{SH}$ 基の 数とヨード量とは逆の相関関係にあると報告している ${ }^{19)}$.

こうした TGB の物理化学的究明, 就中 TGB の degradation に関する研究は独自の領域を持ちながら 発展して来たが，生体に於いて，てれら in vitro で得られた実験結果が in vivo で如何なる意義を有する かについての討論は殆んど行われなかつた。 最近, Ahn とRosenberg ${ }^{20)}$ 及び Peake ${ }^{34)}$ 等は GSH 及び cysteine は甲状腺の加水分解能を促進すると報告した， 然し，彼等の実験ではヨード化の程度の異なる TGB を用いての比較検討は行われなかつた。

こうした観点から, われわれは最近, 蛋白の S-S 結合の還元のために $\beta$-mercaptoethanol を使用し, 乙 の薬物の存在下で標準甲状腺蛋白の pancreatin による加水分解能は促進され，特に蛋白のヨード化の程度 が少いとその加水分解作用を受け易いととを見い出した ${ }^{14)}$. しかし，乙の場合は甲状腺以外にある加水分解 酵素を使用し，又生体にはないと考えられる $\beta$-mercaptoethanol を使用した.

今回の研究においては，蛋白のヨード化の差異に焦点を合わせて，甲状腺には比軹的多量に含まれると考 えられる $\mathrm{GSH}^{3) 4}$ を用い，かつ甲状腺内の加水分解酵素による proteolysis, 所謂 autolysis に及ぼす $\mathrm{S}-\mathrm{S}$ 基の重要性について検討を行つた.

Fig. 1 亿明らかなように, GSH が存在しないと甲状腺 autolysis は殆んど起らないが，GSH の存在下で は明らかに蛋白のヨード化の程度に拘らず autolysis は促進した。 しかし，autolysis の促進効果はLID 飼育 動物から得た甲状腺の方が Purina 飼育動物から得た甲状腺の方より大であつた，との観察は，GSH の加 
水分解促進効果はヨード化の少い甲状腺の方がヨード化の進んだ甲状腺より大であるてとを物語つていると 思われる. GSH の作用は蛋白の $\mathrm{S}-\mathrm{S}$ 基の還元作用である ${ }^{34)}$ ので，蛋白分子内の $\mathrm{S}-\mathrm{S}$ 基を $\mathrm{SH}$ 基に变化さ せることによつて，蛋白分子はより加水分解醏素の作用を受け易くなると考えられる．従つて，われわれは ヨード化の少い蛋白の方が分子内 (intramolecular) 又は分子間 (intermolecular) の S-S 基が対照群任比 較して少いので，一定反応時間内に GSH の作用を容易に受けて subunits 亿崩壊し，引続いて加水分解酵 素作用を受け易いととや， S-S 基間の結合力自体が弱体で SH 基に還元され易く，その結果䤃素の attack 亿敏感であるとと等か摊論し得るであろう。

一方，LID 飼育動物では血中甲状腺ホルモンの低下のために下垂体から TSH が多量に分泌され，血清

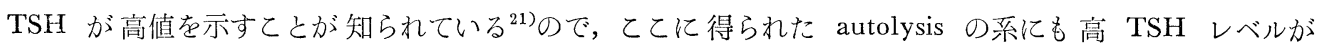
autolysis 亿影響を与えている可能性がある。そてで, Fig. 3 及び Fig. 4 亿於いて autolysis に及ぼす TSH の効果を検討した。 in vivo に多量の TSH を投与して in vitro で autolysis を行つたが，特に TSH の 刺激効果はなかつた，又，in vivo で投与した TSH は in vitro の thyroid protease 活性には全く影響を 与えなかつた。TSH の投与は甲状腺細胞膜を介して adenyl cyclase 活性を高め, 引続いて甲状腺沪胞内に endocytosis させる過程を促進し, 結果的にはコロイド小滴が加水分解醉素と結びついて加水分解過程を促

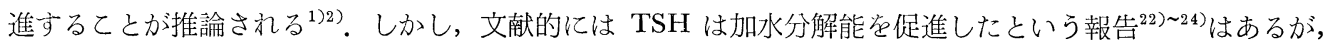
これらはわれわれの実験に用いた $\mathrm{pH} 3.6$ より高い $\mathrm{pH}$ のとてろで加水分解を行つている．彼等は甲状腺 homogenate の加水分解能の optimal pH は 4.0 であるが，外因性 TSH 亿対する反応惊更に高い $\mathrm{pH}$ レベルでのみ発現されることを見出した24). 従つて $\mathrm{pH} 3.6$ の incubation mixture を用いた本実験では TSH 効果が発現されない可能性がある。従つて，ててで得られた in vitro の奏験で LID 飼育動物にみら れた autolysis の刺激効果は少くとも, 内因性 TSH の甲状線加水分解䣲素への直接作用ではなかつたと 考えられるであろう。

次に，上に得られた GSH による autolysis 促進作用は甲状腺加水分解醉素への影響による可能性も否 定出来ない。しかし, 過去の文献 ${ }^{25) ~ 27) て ゙ は ~}$ SDS $^{2526)} や U$ Urea ${ }^{27)}$ 等の蛋白変性物質が thyroid protease 活 性を抑制すると述べている。然るに本実験では $0.05 \mathrm{M} の \mathrm{GSH}$ の添加で加水分解は抑制されることはなく， かえつて促進されるのであるから GSH 自身の影響は多くの蛋白変性物質の作用とは趣きを異にしている と思われる. 事実, Pastan 等 ${ }^{28}$ はラット状腺の alkaline protease は $\beta$-mercaptoethanol の存在下で TGB を強力に加水分解与るととを見出し，その主たる機序は $\beta$-mercaptoethanol が TGB の S-S 基を還

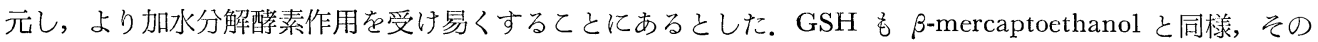
主たる作用は蛋白分子の S-S 基の還元にあるので，本実験において 0.05M の GSH によつてヨード化蛋白 内の $\mathrm{S}-\mathrm{S}$ 基が $\mathrm{SH}$ 基に還元され，乙の变性蛋白が添加された加水分解酵素に攻撃され易くなる可能性を考 えるべきであろう. 又, alkaline protease 活性の発揮し得ないと考えられる Pepsin や thyroid protease による酸性側 $\mathrm{pH}$ を用いた実験でも，GSH の加水分解促進効果が認められているととから，GSH の甲状 腺 alkaline protease への影響は否定し得るであろう.

一方, GSH の比較的高濃度でのみ autolysisの刺激効果が認められた (Fig. 2) が，てのととから in vivo における GSH の役割を直ちに否定する根拠にはならないであらう。われわれの加水分解䤀素添加前の蛋 白と GSH との preincubation は 30 分間であるが，ての時間は蛋白分子内のすべての $\mathrm{S}-\mathrm{S}$ 基を $\mathrm{SH}$ 基へ 還元せしめるには不十分であろうし，したがつて，てれより低い濃度でも長時間作用すれば，同様な効果を 発揮し得る可能性も考光られる。

GSH の有する蛋白の S-S 基の還元作用は加水分解酻素への影響より, TGB への影響を介して発揮され る可能性を更化確認するために甲状腺 autolysis の実験の代りに，ヨード化蛋白と酵素源を分けて標識甲状 腺蛋白を予め GSH で処理した後, 甲状腺由来の crude の thyroid protease や甲状腺由来以外の酵素, 即ち pepsin や pancreatin によつて加水分解を試みた。.Fig. 5. 6 亿示すように，ヨード化蛋白は予め GSH を作用させると pepsin, pancreatin 及び crude の thyroid protease 等, 異なる optimum $\mathrm{pH}$ を有する 
各酥素によつて加水分解され易くなつた。ヨード化の少い蛋白の方がョード化の進んだ蛋白より，より強力 に攻撃を受けるととが，ててでも確認された。 thyroid protease と pepsin との共通性は既に報告されてい る29 〜31)が, 両者共, acid proteinase であり, pepsin-inhibitor である diazoacetylnorleucine methylester によつて抑制され 亿 $^{29)}$, insulin の酸化型 B chain 結合汇対して特異性を有している点 ${ }^{3031)}$, 興味深いと思 われる。

長期間, 抗甲状腺剂を投与すると TGB 量は減少するととが知られている ${ }^{32}$. 従つて，われわれが見い出 した上記の知見は, PTU を使用した LID 飼育動物から得た TGB 量が Purina 飼育動物から得た TGB 量より少いために，おてり得た可能性もあり得るであろう. 特に一定量の酥素との反応の際, TGB 量の少 い方が早く分解されるのは当然の帰結であろう. 従つて, ヨード量の多い甲状腺とヨード量の少い甲状腺と の比較にわいて得られた，われわれの成績から直ちに TGBのヨード化の相異が，その後の autolysis, 又は 加水分解酵素に対する感受性を規定すると断定するには問題があるように思われる. しかし, goitrous patients の甲状腺組織と正常甲状腺組織から，それぞれ得た thyroid extract の平均蛋白量には差異がな ${ }^{18)}$, chick から得た thyroid extract の場合 ${ }^{33)}$, 又, われわれの実験においても, goiter の有無に関係 なく，一定 wet tissue 重量当たりの甲状腺 homogenate の蛋白量には差異がなかつた. 更に，われわれが 既に報告したように ${ }^{14)}$ ，今回の実験条件とほぼ同様の条件下で sucrose gradient ultracentrifuge により得た 18一19 Sの TGB 分画を一定の蛋白濃度に調整してから, $\beta$-mercaptoethanol で処理した後, 一定濃度の加 水分解醅素を作用させても，crude の甲状腺ホモジネートを使用した場合と同様の傾向を示した。この観察 から，われわれはTGB のヨード化の差異が加水分解醉素住対する感受性を左右する重要な因子であると考 えた。しかし，GSH を用いた今回の実験では純化した TGB を使用せず，又甲状腺 homogenate に含ま れる TGB 以外のヨード化蛋白，ヨード化されてない蛋白や組織成分つ混入等が反応系に関与している可能 性が考光られ; 更に今後に検討の余地が残されている.

Takeuchi 等 ${ }^{33}$ は は多量ヨードの甲状腺ホルモン分泌抑制機序として, 多量ヨードが甲状腺 autolysis を抑制 すると報告したが, 彼等は多量ヨード投与は TGB の加水分解に対する stability には影響はないであろう と推論している. 大竹等 ${ }^{34)}$ 多量ヨードによる甲状腺ホルモン分泌抑制機序として，ヨードは TGBの stability 又は加水分解醳素に対する直接作用はなく、ヨード投与により GSH の効果は見られなかつたと発 表している. しかし, 彼等の結果と, TGB のヨード化の程度が GSH の存在下で加水分解過程影響を与 えるとする,われわれの推量とは必ずしも相矛盾するものではない. 彼等は TGB を扱つてはいるが, 彼等 のヨード投与群では低ヨード食飼育動物に大量の KI を注射しており, われわれの実験では Purina で飼育 した動物がれれ相当し, 彼等の低ヨード食飼育動物の対照群に対して, われわれの実験では, PTU 投与 により甲状腺内のヨード化を極端に制限した甲状腺がてれに相当しているので, 実験条件が既に大分異つて いるからである. 事実, 最近, 多量ヨードによる甲状腺ホルモン放出抑制機序として, 山本等 ${ }^{133}$ は多量ヨー ドは cyclic AMP 産生に引き続く過程で抑制効果を発揮するととを見い出した.

最近, Peake 等 ${ }^{4)}$ は TSH 投与後, 甲状腺の $800 \sim 15,000 \times \mathrm{g}$ の particulate fraction $\left(\mathrm{P}_{15}\right)$ は colloid droplet, lysosome, phagolysosome を含んでおり, ての分画には TGB の degradation によつておてる intermediate が存在し, てれは GSH 存在下で TGB と甲状腺 lysosomal enzyme との incubation 中に も, 又見られるとした。 この観察から, 彼等は TGB が lysosome の作用を受ける際に, 甲状腺内におい て GSH が重要な役割を演ずるとした。従つて，われわれの実験結果は甲状腺沪胞へ colloid droplet が endocytosis されたあと, ヨード化の異る colloid droplet 即ち, TBG はそれぞれ, その後の加水分解過程 の速度を異にする可能性を示唆するものと考光る. こうして, TBG は endogenous の加水分解酵素の作用 を受けて, ヨード化ア之ノ酸を遊離する. 次いで, 甲状腺ホルモンは甲状腺から血中へ遊離されるわけであ るが，乙の過程にも複雑な機構 ${ }^{35}$ が考えられ，更に今後の検討を要する問題が残されている. 
結 語

TGB のヨード化の程度の相異が甲状腺ホルモン分泌機構に影響を待つ可能性を探る目的で一連の実験を 行い,以下の結果を得た。

1）ヨード化の少い甲状腺の autolysis は0.05Mの GSH を添加後，ヨード化の進んだ甲状腺の autolysis より容易に促進した.

2) PTU withdrawal 後の低ヨード食で飼育した動物の甲状腺の autolysis の促進は，TSH が thyroid protease 活性を刺激した結果とはいえないと考えられた.

3 ）ヨード化の少い甲状腺蛋白は GSH で処理すると，ヨード化の進んだ甲状腺の場合に比較して容易 に加水分解されることが判つた.

以上の成績と，ヨード化の少い TGB 分子の $\mathrm{SH}$ 基の含有量とヨード化の程度は逆の相関関係にあるとい う最近の報告を考え併せるとヨード化の少い蛋白はヨード化の進んだ蛋白より還元グルタチオンの影響を大 きく受け易いととが判つた，甲状腺内に含有されると考えられる GSH の主たる作用機序は，蛋白の S-S 基を還元することにあるので，てれらの実験的事実は蛋白のヨード化の割合が endogenous の甲状腺蛋白の 加水分解能に影響を与える可能性を示唆するものと考えられる.

本論文の要旨は第45回日本内分泌学会総会に拈いて発表した。

\section{文献}

1) Wollman, S.H., S.S. Spicer, and M.S. Burstone : J. Gell Biol. 21 : 191 (1964).

2) Inoue $K$,

Y. Grimm, and M.A. Greer : Endocrinology 81 : 946 (1967).

3) Peake, R.L., K. Balasubramanian, and W.P. Deiss : J. Biol. Ghem. 241 : 2766 (1966).

4) Peake, R.L., R.J. Cates, and W.P. Deiss, Jr : Endocrinology 87 : 494 (1970).

5) Tarutani, O., and N. Ui : Biochim. Biophys. Acta $181: 116$ (1969). $\quad$ 6) Edelhoch, H., and R.E. Lippoldt : J. Biol. Ghem. $237: 2788$ (1962). 7) Robbins, J. : J. Biol. Chem. $238: 1821963 . \quad$ 8) Nunez, J., J. Mauchamp, J. Pommier, T. Cirkovic, and J. Roche : Biochem. Biophys. Res. Commun. $23: 761$ (1966). 9) Goldberg, I.H., and R.W. Seed : Biochem. Biophys. Res. Commun. $19: 615$ (1965).

10) Ui, N., and O. Tarutani : Gunma Symposia on Endocr. $5: 95$ (1968). 11 ) Inoue. K., and A. Taurog : Endocrinology $83: 833$ (1968). 12) Onaya, T., T. Tomizawa, T. Yamada. and K. Shichijo : Endocrinology $79: 138$ (1966). 13) Yamamoto, K., T. Onaya, T. Yamada, and M. Kotani : Endocrinology $90: 986$ (1972). $\quad$ 14) Kobayashi, I., and M.A. Greer : Endocrinology $89: 1499$ (1971). 15) Kobayashi, I., and M.A. Greer : Endocrinology $89: 756$ (1971). 16) PittRivers, R., and R.R. Gavaliere : Biochem. J. 86 : 86 (1962). 17$)$ Kobayashi, I., and M.A. Greer : Endocrinology $88: 309$ (1971). $\quad 18)$ Beckers, C., and M. De Visscher : J. Clin. Endocrinol. 22 : 711 (1962). 19) Edelhoch, H., M.S. Carlomagno, and G. Salvatore : Arch. Biochem. $134: 264$ (1969). $\quad$ 20) Ahn, C.S., and I.N. Rosenberg : Endocrinology $81: 1319$ (1967). 21) Studer, H., and M.A. Greer : Acta Endocr. (Kobenhavn) $49: 610$ (1965). 22) Balasubramaniam, K., W.P. Deiss, Jr. : W.G. Tan, and R.G. Powell : Endocrinology 77 : 54 (1965). 23) Deiss, W.P., Jr., K. Balasubramaniam, R.L. Peake, J.A. Starrett, and R.G. Powell : Endocrinology 79 : 19 (1966). 24) Konno, N., P.V.N. Murthy, and J.M. McKenzie : Endocrinology $87: 1062$ (1970). $\quad 25)$ Putnam, F.W. : Advan. Prot. Ghem. $4: 79$ (1948). $\quad$ 26) Anfinsen, G.B., and R.R. Redfield : Advan. Prot. Chem. $11: 2$ (1956). $\quad$ 27) Pitt-Rivers, R. : Biochem. J. 90 : 629 (1964). $\quad$ 28) Pastan, I., and S. Almqvist : Biochem. Biophys. Res. Commun. 18 : 332 (1965). 29) Smith, G.D., M.A. Murray, L.W. Nichol, and V.M. Trikojus : Biochem. Biophys. Acta $171: 288$ 
(1969).

30) Sanger, F., and E.O.P. Thompson : Biochem. J. 53 : 366 (1953).

Dopheide, T.A.A., and V.M. Trikojus : Biochem. Biophys. Acta 118 : 435 (1966).

32) Tarutani, O., and N. Ui : Biochem. Biophys. Res. Commun. 33 : 733 (1968). 33) Takeuchi, K., H. Suzuki, M. Sawada, and Y. Horiuchi : Endocrinology $86: 1239$ (1970).

34）大竹正夫, 女屋 敏正, 小谷雅宣, 佐藤 晁, 山田隆司 : 日本内分泌学会東部部会, 6 月例会 (1972). 35) Greer, M.A., Y. Grimm, and K. Inoue : Endocrinology 85 : 837 (1969). 